DOI https://doi.org/10.36059/978-966-397-159-9/18-35

\title{
CHARACTERISTIC FEATURES OF COMBATING CROSS-BORDER CRIME ON THE SEA ROUTES AND IN THE AIRSPACE
}

\section{Stanislav Filippov}

\section{INTRODUCTION}

More than 420 million containers are moved around the world annually by sea, carrying $90 \%$ of the world's cargo. Only $2 \%$ of them are controlled ${ }^{1}$. Most of them are used for legal transportation, but some - for smuggling drugs, weapons and people. One sea shipment of contraband is ten times larger than the volume of automobile and hundreds of times - the volume of pedestrian ones. The situation poses a serious security risk, therefore in 2003 UNODC, together with the World Customs Organization, developed a Container Control Programme. The Programme aims to assist states in establishing a system to counter smuggling at seaports. Although, the causes of another problem, which is closely linked to cross-border crime on sea routes - mass migration movements caused by human rights violations, conflict and poverty, remain unresolved. In these conditions, migration by sea is a forced step for hundreds of thousands of people in the world to improve their lives. In these circumstances, tens of thousands are trafficked illegally, often in dangerous ways. High profits from the illicit cross-border trafficking of people and movement of drugs encourages criminals to search for alternative methods of transportation. The increase in forces and means for reliable border protection has a drawback - offenders are looking for ways to modernize their cross-border criminal activity.

In operational and service practice of Ukrainian law enforcement agencies there were cases of termination of offenses which were carried out by means of both construction of static objects (tunnels, pipelines), and by crossing the border using various vehicles (sea vessels of tourist class, rafts, ferries, uncontrollable railway carts, unmanned aerial vehicles). A special

1 Ukrayina pryyednalas' do hlobal'noyi systemy kontrolyu za nezakonnym obihom narkotykiv, zbroyi ta fal'syfikatu. [Ukraine has become a part of the global system of control over illegal drug trafficking, and that is counterfeit] 16.01.2018. Derzhavna fiskal'na sluzhba. Of.portal. URL: http://sfs.gov.ua/data/files/219105.pdf 
place in this regard belongs to the means of aviation. These circumstances together determine the relevance of this work

1. Combating cross-border crime in maritime space

The international community, in the course of many years of cooperation between the states in the maritime space, has accumulated experience in responding to the most common criminal threats in the modern world, such as: container smuggling, smuggling of illegal migrants and victims of trafficking by sea (often at risk to their lives), involvement of seamen in criminal offences abroad.

As for the problem of container smuggling, at the present stage of technology development, it is partially solved by scanning containers with various systems, such as MMPDS, which is common in many countries, a multi-mode passive system that is able to scan 100 percent of all cargo containers that enter ports. At the same time, this technology, mainly through a high standard of compliance with radiation safety requirements, is quite valuable, it is difficult to provide it to all ports, and when this happens, containers with contraband will obviously be overloaded at sea to smaller vessels that will avoid calling at ports where there is an automatic control system.

The Global Container Control Programme (GCCP) established by UNODC and the World Customs Organization has been in operation since 2004. The purpose of the GCCP is to prevent the illegal movement of drugs, weapons, counterfeit goods. As of 2018, 48 states were members of the GCCP. Ukraine, after its accession to the program, has introduced the port control units in the BCP «Odessa Commercial Sea Port» and «BoryspilAirport» (Air cargo). The state customs service gained access to the Container COMM information system, which was introduced by the World Customs Organization for the purpose of exchanging information on highrisk containers (type of cargo, route, payment methods, etc.) ${ }^{2}$. In general, the technological support of maritime traffic control is built taking into account the fact that the commission of offenses at sea involves extremely widespread logistics network, which includes ships, customs warehouses, dutyfree shops, etc. According to the UN Convention on the law of the sea (articles 3, 8, 33), the following maritime zones are established: inland waters, territorial waters, adjacent zone, IM (E) $Z^{3}$ (Fig. 1).

\footnotetext{
${ }^{2}$ Ibid

${ }^{3}$ United Nations Convention on the Law of the Sea (1982). URL: https://www.un.org/ depts/los/convention_agreements/texts/unclos/unclos_e.pdf
} 


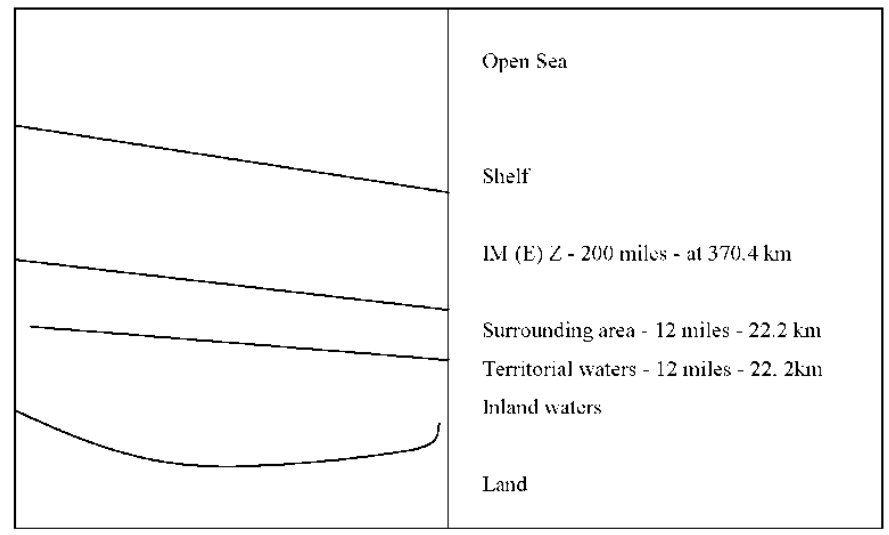

Fig. 1. Maritime zones according to the UN Convention on the law of the sea

It should be noted that the only body that in Ukraine is able (due to the availability of forces and means) to monitor the surface situation at sea and has the legal authority to stop, inspect non-military vessels that have committed violations of the law during navigation and stay in the adjacent zone, the territorial sea, internal waters, as well as vessels and watercraft that are working in the IM (E) Z, and stop working in the absence of permission of the SBGSU. Also the powers of the SBGSU include detaining vessels that violate the legislation on the IM (E) Z, the adjacent zone of Ukraine or the norms of international law, and deliver them to one of the ports of Ukraine open to foreign non-military vessels. The rights to detain or arrest ships and / or their crew members do not apply to warships and other government vessels used for non-commercial purposes ${ }^{4}$.

According to p. «g» part.5 article. 18 of the Law «On the organizational and legal basis of the fight against organized crime SBGSU is obliged to «carry out actions to control and detain Ukrainian and foreign non-military vessels».

Given the lack of forces and means to perform tasks being analysed of other public authorities, in our opinion, it should be resolved in a normative way participation of the marine guard of the SBGSU in various maritime operations under the auspices of FRONTEX, given that the authority of the

${ }^{4}$ Pro prylehlu zonu Ukrayiny : Zakon Ukrayiny vid 6 hrudnya 2018 r. [Adjacent Area of Ukraine: Law of Ukraine of December 6, 2018]. № 2641-VIII. URL: https://zakon.rada.gov.ua/ laws/show/2641-19/print 
marine protection of the SBGSU apply to the marine area of the state border with a length of 765 miles (of these, 509 miles - the Black sea, 132 miles the sea of Azov and 26 miles - the Kerch Strait. The length of the border river section along the Danube is 98 miles. The area IM (E) $\mathrm{Z}$ reaches over 21 thousand square miles. Since 2014, Ukraine has not controlled 413 miles of the marine area of the state border (of which 290 - in the Black sea, 97 in the Azov and 26 miles of the Kerch Strait). In IM (E) Z - more than 15 thousand square miles. The SBGSU carries out border control at 28 checkpoints for sea traffic in the waters of the Black and Azov seas and river Danube.

The 1982 UN Convention on the law of the sea grants the right to coastal states to establish laws and regulations relating to the peaceful passage across the territorial sea (article 21). The corresponding control is usually carried out in the adjacent area. The purpose of this control is the prevention within the territory or territorial sea of the coastal state of customs, immigration offenses, as well as bringing to justice for their commission. On these issues, such a state also has exclusive jurisdiction over artificial islands, installations and facilities in the exclusive maritime economic zone ${ }^{5}$.

The EU experience in reforming the system of combating cross-border threats in the maritime space is indicative. Since the functions of countering various threats at sea, including criminal, are performed by more than 300 different bodies and services of the EU member-states, in 2016, in addition to the creation of the European border and coast guard on the FRONTEX platform, the project «Coordination of the functions of the coast guard of the European Union» was implemented. It provides for the integration of technical (aviation, unmanned aerial vehicles, marine watercraft, and related surveillance equipment) capabilities of the three institutions for the joint implementation of tasks on the maritime border of the EU: FRONTEX (Warsaw, Poland - Border And Coast Guard, EMSA (Lisbon, Portugal) Maritime Security and EFCA (Vigo, Spain) - control over the extraction of biological resources.

Progress in changes in the criminal situation in the cross-border sphere becomes noticeable when the system of counteraction measures corresponds to the global nature of the threat. This can be demonstrated by the example of the formation of an unprecedented system of international political, legal, diplomatic and other (even military!) measures to combat crime related to the illegal transfer of migrants to the EU, which was formed in 2015-2016. This system provided for:

\footnotetext{
5 United Nations Convention on the Law of the Sea (1982). URL: https://www.un.org/depts/los/convention_agreements/texts/unclos/unclos_e.pdf
} 
adoption of agreements between the EU and transit countries (Turkey) and countries of origin of migrants ( 7 countries in Africa and 2 countries in the Middle East,

expanding the powers of the maritime forces of countries involved in combating cross-border crime (UN Security Council resolution No. 2240),

operations of international organizations to counter human trafficking and illegal migration,

institutional development of the system for countering cross-border threats,

naval operations (NATO in the Aegean sea),

globalization of the European border surveillance system (EUROSUR).

The crisis phenomena that were observed in Europe in 2015 stipulated if not revolutionary, then very non-standard answers. For example, such a nonstandard response may well be considered an unprecedented decision to use the forces and means of the military-political Alliance, which is NATO in a purely police operation in the Aegean sea ${ }^{6}$. This clearly demonstrates the international globalization of efforts to counter the global threat posed by cross-border crime associated with the smuggling of migrants. It is obvious that the effectiveness of combating smuggling on sea routes is associated with the effectiveness of joint international and interdepartmental activities, which, in turn, depends on the functional and operational compatibility of heterogeneous forces and means, including FRONTEX forces and the relevant regulatory norms.

A separate problem is the participation of Ukrainian citizens in crossborder criminal associations operating in the sea. The urgency of this problem is due to the increase in the number of cases of bringing Ukrainian sailors to responsibility by law enforcement agencies of foreign countries for the transportation of illegal migrants, as well as smuggling of explosives and tobacco products. As an example, let us recall the situation in the Mediterranean, which had a noticeable resonance in 2018. We are talking about dozens of Ukrainian sailors detained by law enforcement agencies of Greece and Italy for complicity in the illegal cross-border movement of migrants and smuggling. This happens mainly on the Mediterranean routes from Turkey to the countries of southern Europe. But there are other cases. For example, FRONTEX reports include information about citizens of Ukraine who were skippers of watercraft, who transported from Turkey to

6 Pilot project "creation of a european coastguard function" final report. URL: http://frontex.europa.eu/assets/Publications/General/Final_Report_EUCG.pdf 
Italy citizens of Pakistan, Syria, Iraq, Afghanistan, Iran and Somalia ${ }^{7}$. In particular, vessels with Ukrainians on Board were detained in ports of Greece, Italy, France, Spain, Libya and Nigeria. Members of the teams of these vessels are recruited, as a rule, in the Ukrainian black sea region, without even necessarily maritime skills, people usually are explained the real purpose, which is to transport migrants.

We quite agree with the thesis of Louise I. Shelley, who suggests that some categories of border areas are particularly vulnerable to transnational crime problems, as is the case in the above example, when recruitment of personnel is conducted for working on those Mediterranean (mainly) routes, which are characteristic also for the illegal transportation of migrants ${ }^{8}$.

For example, 12 sailors from the ship Mekong Spirit, accused of smuggling industrial explosives and detonators, were dismissed in Greece from custody in July 2018 by the efforts of the diplomatic institution of Ukraine. Based on media reports, this did not solve the legal problems associated with the investigation of specific crimes and, especially, with the prevention of crime in the field of migrant smuggling. On the contrary, a joint investigation would provide an understanding of the mechanism of those crimes committing, as well as elements of the system of determination of these crimes, such as victimization factors. Therefore, there would be exactly these situation data and information about the causal complex of crimes, the account of which is necessary when planning the necessary measures for both general social and special criminological crime prevention. Until now, it remains only to record the convictions of Greek justice against citizens of Ukraine, at least 150 of whom as of the end of 2018 were in Greece awaiting sentence for committing cross-border crimes ${ }^{9}$. And in general, as of 09.10.2018, more than 290 Ukrainian sailors were detained in penitentiary institutions abroad. In matters of preventive activities, it is necessary to take into account the specifics of the involvement of Ukrainian sailors in criminal activities, the reasons that prompted them to voluntarily agree to doubtful work, and, on this basis, to take the necessary measures to prevent cross-border crime. And these measures have to be

7 Risk Analysis FRAN.Q1.2017. Warsaw, July 2017. 37 p. P. 20 URL: https://frontex.europa.eu/assets/Publications/Risk_Analysis/FRAN_Q1_2017.pdf

${ }^{8}$ Shelley L. A Hazy Crisis: Illicit Cigarette Smuggling in the OSCE Region” July 19, 2017. P. 258 URL: https://www.csce.gov/sites/helsinkicommission.house.gov/files/Cigarette Smuggling.pdf

9 Filippov S. (2019) Protydiia transkordonnii zlochynnosti: hlobalnyi kontekst $i$ realii Ukrainy: monohrafiia [Countering cross-border crime: the global context and realities of Ukraine] Odesa: Feniks. 452 p. (in Ukrainian) 
planned taking into account the changing of environment, with correction, judging by estimates of their effectiveness ${ }^{10}$.

\section{Countering cross-border offences in airspace}

The cross-border use of aircraft in violation of the established procedure is a criminal offence regardless of the presence and nature of the cargo. Their application technically allows rapid transportation of persons and cargo without passing border control and without customs control. The logic of our work involves the study of criminologically significant aspects of combating crime in this area. The criminogenic danger of the use of aviation (including with small aircraft) is that this use is equivalent to the use of airspace in the interests of criminality, which allows one to quickly and bypassing border control transport a significant number of persons who may belong to the category of foreign terrorists-fighters, persons wanted for crimes, persons who are prohibited from entering / leaving, or irregular migrants. Also, air transport allows bypassing customs control to transport a variety of goods, as well as items and substances seized from civil and economic turnover. These circumstances actualize the study of the criminal potential of the use of aircraft for the purpose of committing cross-border crimes.

These circumstances require the study of criminal risks of the use of airspace in the border area. Based on the above, the purpose of this work is to study the dynamics and criminological features of the use of aircraft in the context of trends in cross-border crime. An additional objective is to forecast trends in criminology, taking into account the rapid development of the digital world in general and the technologization of crime in particular.

To achieve this goal, we used the analysis of scientific sources and official statistics to determine criminal threats in the use of airspace when crossing the state border, namely, the data of the Unified report on criminal offenses, as well as the analysis of the content of court decisions. The scientific study also provides for a comparative analysis of analytical data on the activities of operational and search units of the State border guard service of Ukraine and the data of the report of the Department of Homeland Security (DHS) of the United States (Agency, which includes the US Customs and Border Control - US CBP).

General characteristics of the rules governing international flights.

${ }^{10}$ Filippov S. (2019) The Smuggling of Tobacco Products in Europe: Criminogenic Potential Capacity. Baltic Journal of Law \& Politics. № 12 (1). P. 35-61. DOI: 10.2478/bjlp2019-0002. URL: https://content.sciendo.com/view/journals/bjlp/bjlp-overview.xml 
With the development of aviation in the thirties of the twentieth century there was a need for the regulation of criminal liability for violation of the rules of international flights. Obviously, in the conditions of the model of protection of the state border, which provided for the «iron curtain», the corresponding norm on criminal responsibility did not work in practice, since the aircraft violators were destroyed by means of air defense. All the more was resonance from actions of the unprofessional pilot, German citizen Matthias Rust, which on the 28 May 1987 on light plane «Cessna 172 Skyhawk» carried out the flight from Helsinki, without authorization crossed the state border of the USSR, without counteraction from Air Defense made a flight to Moscow and even landed on the Red Square. This case resulted in a change of Union legislation and amending the Law on state crimes of 1958 with an article «Violation of the use of airspace».

But in modern conditions, the purpose of international flight with violation of the established rules is often not air hooliganism, but illegal transportation of persons or objects across the state border. In general, an illegal act with this purpose may be qualified under the following provisions of the Criminal Code of Ukraine: article 334 «Violation of the rules of international flights», article 281 «Violation of the rules of air flights», article 204 «Illegal manufacture, storage, sale or transportation for the purpose of selling excisable goods». Also, the pilot is liable under article 204-1 of the Criminal Code «Illegal crossing or attempted illegal crossing of the state border of Ukraine». In recent years, with the participation of operational-search units of the SBGSU, a number of criminal offenses under article 334 of the Criminal Code of Ukraine «Violation of the rules of international flights» have been effectively stopped.

Therefore, an international flight is associated with crossing of the state border of Ukraine and another state by an aircraft, or a flight performed in the airspace of another state (other states) ${ }^{11}$. The offence in question may take the form of entry into or departure from Ukraine without a permit, as well as non-compliance with the routes and corridors specified in the permit, as well as echelons and landing places. In this case, the air route is a controlled airspace (or part of it) in the form of a corridor. The procedure for crossing the state border by aircraft is determined by the aviation rules of Ukraine. In particular, it is found that «aircraft cross the state border on

${ }^{11}$ Pravyla pol'otiv tsyvil'nykh povitryanykh suden u povitryanomu prostori Ukrayiny. Ministerstvo infrastruktury Ukrayiny, zatverdzheni nakazom Ministerstva infrastruktury Ukrayiny vid 28.10.2011 № 478. [Flight rules for civil aircraft in the airspace of Ukraine. Ministry of Infrastructure of Ukraine, approved by the order of the Ministry of Infrastructure of Ukraine] № 478. From October 28, 2011/ URL: https://zakon.rada.gov.ua/laws/show/z1327-11. 
specially designated routes, i.e. in a limited height and width of the airspace intended for crossing the border» ${ }^{12}$. Beyond these routes crossing the state border is possible in some cases, in fact, force majeure, for example, to perform emergency work or international agreements in the event of a natural disaster or by permission of the General Staff of the Armed Forces of Ukraine and coordination with the Administration of the SBGSU, or in the event of an emergency situation during the flight, which poses a threat to flight safety and human life ${ }^{13}$. The grounds for crossing the border by civil and state aircraft performing international flights with landing (departure) on (from) the territory of Ukraine is a permission to conduct flights and the presence of a flight plan. The basis for crossing the border by civil aircraft transiting through the airspace of Ukraine is the presence of a flight plan (section XI of the Aviation rules of Ukraine). In practice, this means that prior to the start of the flight with the crossing of state borders, the Air Traffic Service Authority (ATS) receives information about this in the format of the flight plan (flight plan - FPL).

It is also important that the navigational training of the crew, which performs an international flight, involves knowledge not only of the position of the corridors of flight, but also of the configuration of the border.

According to the Rules for 75-100 km before crossing the state border of Ukraine, the aircraft commander requests a dispatcher of an appropriate air traffic service a permission to cross the state border and report to him the echelon (height) of flight and the calculated time of flight over the state border of Ukraine ${ }^{14}$. During the crossing of the state border of Ukraine, the crew of the aircraft reports to the dispatcher the actual time of crossing and the echelon (altitude) of the flight. Crossing the state border by an aircraft without radio communication is prohibited. An aircraft that has crossed the state border of Ukraine without a permit or committed other violations of the rules of flight across the state border of Ukraine or the procedure of the runway of Ukraine shall be considered an aircraft-violator and shall be forced to land if it does not comply with the requirements of the air traffic

\footnotetext{
${ }^{12}$ Pro zatverdzhennya Aviatsiynykh pravyl Ukrayiny «Pravyla vykorystannya povitryanoho prostoru Ukrayiny : nakaz Derzhaviasluzhby Ukrayiny, Minoborony Ukrayiny vid 11 travnya 2018 № 430/210. [On approval of the Aviation Rules of Ukraine «Rules of use of the Ukrainian airspace: order of the State Aviation Service of Ukraine, Ministry of Defense of Ukraine of May 11, 2018 No. 430 / 210]. URL: https://zakon.rada.gov.ua/laws/show/z1056-18.

${ }^{13}$ Ibid.

${ }^{14}$ Pro zatverdzhennya Aviatsiynykh pravyl Ukrayiny «Pravyla vykorystannya povitryanoho prostoru Ukrayiny : nakaz Derzhaviasluzhby Ukrayiny, Minoborony Ukrayiny vid 11 travnya 2018 № 430/210. [On approval of the Aviation Rules of Ukraine «Rules of use of the Ukrainian airspace: order of the State Aviation Service of Ukraine, Ministry of Defense of Ukraine of May 11, 2018 No. 430 / 210]. URL: https://zakon.rada.gov.ua/laws/show/z1056-18 .
} 
control bodies. Ukrainian aircraft returning from abroad may cross the state border regardless of the availability of a flight permit. In the absence of such permission, the commander of the aircraft is obliged to land at the international airport determined by the Ukrainian Air Center (section XI of the Aviation rules of Ukraine). Therefore, violation of these norms on a manned aircraft is likely to have a consequence of prosecution under article 334 of the Criminal Code of Ukraine.

\section{Violation of the rules of international flights as a cross-border crime: some indicators of dynamics and geographical features}

Dynamics of registered according to the Unified report offenses under Art. 334 of the criminal code of Ukraine: in 2014, 18 crimes were registered, in $2015-1$, in $2016-4$, in 2017-2, in 2018- $5^{15}$.

For comparison, we present data on manned flights abroad. According to the U.S. Department of Homeland Security (DHS), from 2011 to 2016, smugglers made at least 534 illegal flights across the U.S. border in helicopters, single-engine aircraft or hang-gliders ${ }^{16}$ According to the press data of the period 2011-2017, there were recorded 562 such cases ${ }^{17}$. The offenses were recorded on the southern border of the United States with Mexico) in the States of Arizona, California, New Mexico and Texas. 98 percent of these offenses were related to the transportation of marijuana (seized 22,000 pounds (nearly 10 tons) of marijuana). Less than two percent of the crimes involved methamphetamine smuggling (nearly 8 kilograms of methamphetamine seized). The Report indicates that pilots fly primarily at low altitude over difficult to reach terrain, which makes it difficult for US CBP (Customs And Border Protection) agents to identify them. The plane can carry about 200 pounds $(90 \mathrm{~kg})$ of drugs. Pilots in most cases did not land in the United States, and dropped the cargo.

Indicative for Europe was the Mediterranean route from Morocco to Spain. Given the intensification of the efforts of the Spanish border guards at

15 Yedynyy zvit pro kryminal'ni pravoporushennya. Forma № 1 (misyachna) : nakaz Heneral'noyi prokuratury Ukrayiny vid 23 zhovt. 2012 r. № 100 [Report on criminal offenses. Form No. 1 (monthly): Order of the Prosecutor General's Office of Ukraine dated 23 October. 2012 № 100]. URL: https://www.gp.gov.ua/en/stst2011.html?dir_id=113897\&libid=.

${ }^{16}$ Border security: additional actions could strengthen dhs efforts to address subterranean, aerial, and maritime smuggling. gao-17-474: published: may 1, 2017. publicly released: may 1, 2017. url: https://www.gao.gov/assets/690/684408.pdf.

${ }^{17}$ Illicit drone flights surge along U.S.-Mexico border as smugglers hunt for soft spots. The Washington Post. June 24, 2018. URL: https://www.washingtonpost.com/world/nationalsecurity/illicit-drone-flights-surge-along-us-mexico-border-as-smugglers-hunt-for-softspots/2018/06/24/ea353d2a-70aa-11e8-bd50b80389a4e569_story.html?utm_term=.93f5b72c77f1 
sea, there is an increasing use of offenders' capabilities of small aircraft. In Spain with the use of aircraft the illegal migrants are smuggled in, as well as $\operatorname{drugs}^{18}$.

The court verdicts we analyzed in the period of 2015-2018 showed that all cases of prosecution under article 334 of the criminal code concerned the movement of tobacco products or illegal migrants.

It should be noted that cases of use of motor-paragliders by offenders are becoming more frequent. This is, among other things, due to the fact that a motor-paraglider or glider is subject to registration in the state register of civil aircraft, and the paraglider, motor-paraglider, hand-glider or deltaglider are exempt from these procedures. At the same time, these aircraft can be quickly put together and apart and have a load capacity from 30 to $100 \mathrm{~kg}$ of cargo. And the load capacity of modern motor hand-gliders allows you to transport several boxes of cigarettes, which makes it extremely cost-effective every flight on the Romanian, Hungarian, Slovak and Polish segment of the state border. Motor hand-gliders are equipped with a device for dumping cargo, which allows not to land and minimizes the possibility of termination of the pilot's activities on the territory of a foreign country.

There are quite dramatic examples of the illegal use of small aircraft to move cigarettes across the border. For example, according to Romanian press reports, the wreckage of a Ka-2 helicopter was found near the village of Sepinza in Romania on May 9, 2019. It is noted that the helicopter crossed the airspace of Romania illegally, and was transporting cigarettes. According to the press, the pilot was a 48 -year-old citizen of Belarus, who specially arrived from Minsk by train to Ukraine.

The use of unmanned aerial vehicles: the tendency of intensification of cross-border illegal activities in the coming years

The tendency of technical development of illegal cross-border activity (which causes its intensification) is the use of unmanned aerial vehicles (UAVs, drones) in the border area. An unmanned aircraft designed to perform a flight without a pilot on board, the flight control of which is carried out with the help of a special control station located outside the aircraft. Flights of unmanned aerial vehicles are carried out according to the requirements of Aviation regulations. Flights of unmanned aircraft weighing up to $20 \mathrm{~kg}$ inclusive are carried out without filing applications, without

\footnotetext{
${ }^{18}$ Filippov S. Dynamics and Geographical Distinctions of Crime connected with Migrants' Moving to Europe on Different Routes. NATO Science for Peace and Security Series - E: Human and Societal Dynamics. Addressing Security Risks at the Ukrainian Border Through Best Practices on Good Governance: Editors R. Kęsek at al. 2016. Amsterdam: IOS Press. Volume 129. 129 p. P. 21-27. URL: https://doi.org/10.3233/978-1-61499-710-8-21.
} 
informing the State border guard service of Ukraine, meeting the requirements of not crossing by the UAV of the state border of Ukraine.

According to the data based on the results of operational and service activity of the state border guard service of Ukraine, UAVs are used by offenders for such purpose as:

1) monitoring the movement of border guard details, observing of the order of service as for the time and manner;

2) identification of convenient places for preparation for committing an offense from the point of view of the terrain, other natural and geographical signs, economic activity of local population;

3) transportation of various items across the state border, most often tobacco products.

Cases of termination by units of border protection of such actions are already recorded by tens. In the area of the Western Regional Directorate and Lutsk Detachment in 2018 there were recorded and taken into account:

157 cases $(2017$ - 160) of violations of the state border of Ukraine in the airspace (45 UAVs, 2 aircraft, 110 aircraft were not classified);

19 cases of detention (identification) of aircraft (14 UAVs, 1 aircraft, 2 paratrakes, 3 motor hand-gliders (2017-8);

40 cases $(2017-11)$ of violations of flight rules in the zone with a special order of use of airspace (35 UAVs, 5 aircraft were not classified).

The tobacco products are most often smuggled using small aircraft, including unmanned ones,

The following examples of drone use by offenders are considered typical:

December 2018 - on the border sector of the Mukachevo Border Detachment was organized surveillance of the movement of border guard details with the help of a quadrocopter;

November 2018 - the transfer of 4,500 packs of cigarettes to Hungary using a drone was stopped at the border sector of the Chop Border Detachment;

October 2019 - at the border sector of the Chop Border Detachment, the smuggling of cigarettes into the territory of Slovakia using a quadrocopter was stopped;

August 2018 - a quadrocopter was flown from Romania and landed on the territory of one of the premises at the Mukachevo Border Detachment. When border guards identified the location of the quadcopter, the officer was attacked local residents. 
The latter case confirms the relevance of our study of the criminal potential of the activities of the local population of the border ${ }^{19}$. In fact, we again state that one of the factors that form criminal threats in the border area is the collaboration of the local population with crime, that is, what $\mathrm{N}$. A. Orlovska calls the criminal opposition to protective activity and the reason for which in the literature is called the illegal mentality ${ }^{20}$.

Obviously, it is necessary to analyze and take into account foreign experience, which confirms the constant increase in the number of cases of UAV use by offenders with the same purpose as in Ukraine, and already on a much larger scale. In particular, the first known case in China of crossborder movement of contraband goods on a large scale with the help of drones is considered to be a very illustrative example. In Shenzhen, a major technology center (the so-called Silicon valley of China), 26 people were arrested in February 2018 for smuggling smartphones worth about $\$ 80$ million from Hong Kong to Shenzhen using UAVs and other equipment. These individuals typically operated for 5 hours 15 nights a month, transferring from 10,000 to 15,000 smartphones per night ${ }^{21}$.

To counteract crime in the airspace in the border area the State border guard service of Ukraine at the end of 2018 used 21 UAV systems, each containing 3 UAVs listed in the state register of aircraft. These funds are subject to a significant quantitative increase in 2019. At the same time, there is an obvious need to ensure interdepartmental and cross-border cooperation and interoperability of law enforcement agencies. Indeed, counteraction to this phenomenon by the forces of only the border guard service loses its meaning, because:

airstrips are established outside the controlled border areas and beyond the territorial boundaries of the border guard units;

delivery of aircraft on the ground is carried out covertly in closed vehicles, often in a semi-disassembled form;

in case of movement across the border of various goods, objects, persons, offenders synchronize actions with other accomplices on time and a place.

19 Filippov S. (2017) Obyvatel'i transgranichnaya prestupnost'. [A Common man and Cross-border Crime]. Pravova derzhava (Constitutional State) No 28. P.107-112.

${ }^{20}$ Orlovskaya N (2018) [Criminal threats to the security of cross-border cooperation]. Kryminal'ni zahrozy bezpetsi transkordonnoho spivrobitnytstva. Visnyk Natsional'noyi akademiyi Derzhavnoyi prykordonnoyi sluzhby Ukrayiny. Yurydychni nauky. 2018. № 2. 2018. No. 2. URL: https://nadpsu.edu.ua/wp-content/uploads/2018/11/visnik_2_2018_ur.pdf.

${ }^{21}$ Gangs used drones and pulleys to smuggle $\$ 80$ million in smartphones from Hong Kong, officials say. The Washington Post. April 2, 2018. URL: https://www.washingtonpost.com/ news/morning-mix/wp/2018/04/02/gangs-used-drones-and-pulleys-to-smuggle-80-million-insmartphones-officials-say/?noredirect $=$ on\&utm_term $=.9960 \mathrm{~b} 6032 \mathrm{c} 8 \mathrm{c}$ 
So, in summary, we can note that this method of counteraction is actually reactive (in the context of responding to the challenges that have already emerged, and not ahead of time), and it is possible to use it only with significant funding, and in the digital world it is effective only if combined with other methods. The most important among them are economic (reduction of profitability of «air smuggling»), legal (revision of sanctions provided for «air crimes» at the border, possible criminalization of movement of certain groups of goods across the border), organizational (regarding cross-border law enforcement cooperation) ${ }^{22}$.

So, we have revealed the logic of the approach to the use of aircraft as a tendency that will determine the direction of intensification of cross-border illegal activities in the coming years.

On the basis of the identified threats, it is necessary to state that the problematic issues of combating cross-border crime in the field of aircraft use are concentrated in such areas:

1. Legal. The prospect of criminal liability has no deterrent effect because of the extreme leniency of sanctions. In case of using UAVs for committing cross-border offense, it is possible to bring an offender only to administrative responsibility, which does not deter this person.

2. Economic. The offender is motivated by the prospect of obtaining benefits, which is due to the extremely large difference in the prices of the goods being transported, and, accordingly - high profitability of the transportation.

3. Ensuring interdepartmental and cross-border cooperation and interoperability of law enforcement agencies.

4. Technical issues:

not all types of aircraft are subject to registration in the State Register of civil aircraft and not all aircraft have a SSR receiver-transmitter on board;

the use of modern aircraft with high technical characteristics (aircraft, navigation and lifting) will become more and more widespread. This should be provided for in the counteraction programmes, especially when budgeting for the purchase of equipment with characteristics higher than that used by offenders.

22 Filippov S. O. Zastosuvannya lital'nykh aparativ yak tendentsiya rozvytku transkordonnoyi zlochynnosti u tsyfrovomu sviti [The use of aircraft as a tendency of crossborder crime in the digital world]. Visnyk Natsional'noyi akademiyi Derzhavnoyi prykordonnoyi sluzhby Ukrayiny. Yurydychni nauky. Bulletin of the National Academy of State Border Guard Service of Ukraine. Legal science. 2018. Vol. 4. URL: http://nbuv.gov.ua/UJRN/vnadpcurn_2018_4_7 


\section{CONCLUSIONS}

1) The main efforts to counter cross-border threats on sea routes should be directed to countering the involvement of Ukrainian seamen in container smuggling and smuggling of illegal migrants and victims of human trafficking by sea. To do this, it is necessary to take measures to regulate the possibility of participation of Ukrainian law enforcement officers in FRONTEX maritime operations. In turn, the study of the deterministic complex of this phenomenon will be possible provided the organization of joint investigations under article 18 of the Agreement between Ukraine and the European Police Office on operational and strategic cooperation.

2) Criminology in its development cannot but take into account the rapid development of the digital world in general and the technologization of crime in particular. One of the forms of such technologization in the coming years will be the total use of the airspace with criminal purposes.

3) It is obvious that cross-border crime is already demonstrating the pattern in which this will occur. The aircraft, for example, will be used to: neutralize the technical system of crime prevention and to monitor the actions of law enforcement; preparation for committing of an offense by identifying convenient places in terms of security, access roads; rapid delivery of tools and means of committing a crime, etc.

4) Intensive development of UAVs, obviously, requires not only technological measures of counteraction, but also legal solutions that should regulate their use in special zones, as well as normative regulation of the use of artificial intelligence in UAV control systems to prevent crime. In this regard, innovative transformations depend on the susceptibility of the system to the introduction of the concept of «intellectual development» on the basis of regional clustering of combating cross-border crime.

Thus, promising areas of criminological research are grounded on the bases of new criminal tendencies caused by scientific and technological progress.

\section{SUMMARY}

The article describes the importance of of combating cross-border crime on the sea routes and in the airspace as an element of crime counteraction mechanism.

The problem, which is resolved to achieve this goal, is a theoretical analysis of the peculiarities of cross-border crimes, allowing to detect and otherwise counteract them using such an element of the counteraction mechanism. 
Strengthening the capacity of crime through the use of airspace and on the sea routes is a significant threat to border security, especially during the development of digital technologies. The article includes conclusions formulated on the basis of the worked out factual basis concerning 1) development of criminology taking into account the rapid development of the digital world in general and the tecnification of crime in particular;

2) formulated forecast of trends that will determine the use of aerial vehicles in the interests of cross-border crime;

3) advisable directions of criminological research through criminological knowledge extension with new branches caused by scientific and technological progress.

The article advanced an idea on the prospects of ontogenesis of the part of criminology devoted to the development of tecnification in various spheres.

In matters of preventive activities, it is necessary to take into account the specifics of the involvement of Ukrainian sailors in criminal activities, the reasons that prompted them to voluntarily agree to doubtful work, and, on this basis, to take the necessary measures to prevent cross-border crime. And these measures have to be planned taking into account the changing of environment, with correction, judging by estimates of their effectiveness.

\section{REFERENCES}

1. Ukrayina pryyednalas' do hlobal'noyi systemy kontrolyu za nezakonnym obihom narkotykiv, zbroyi ta fal'syfikatu. [Ukraine has become a part of the global system of control over illegal drug trafficking, and that is counterfeit] 16.01.2018. DFS. Of.portal. URL: http://sfs.gov.ua/data/files/ 219105.pdf

2. United Nations Convention on the Law of the Sea (1982). URL: https://www.un.org/depts/los/convention_agreements/texts/unclos/unclos_e.pdf

3. Pro prylehlu zonu Ukrayiny : Zakon Ukrayiny vid 6 hrudnya 2018 r. [Adjacent Area of Ukraine: Law of Ukraine of December 6, 2018]. № 2641VIII. URL: https://zakon.rada.gov.ua/laws/show/2641-19/print

4. Pilot project "creation of a european coastguard function" final report. URL:http://frontex.europa.eu/assets/Publications/General/Final_Report_EUCG. pdf

5. Warsaw Summit Communiqué Issued by the Heads of State and Government participating in the meeting of the North Atlantic Council in Warsaw 8-9.07.2016. URL: https://www.nato.int/cps/en/natohq/official_ texts_133169.htm 
6. Risk Analysis FRAN.Q1.2017. Warsaw, July 2017. 37 p. URL: https://frontex.europa.eu/assets/Publications/Risk_Analysis/FRAN_Q1_201 7.pdf

7. Filippov S. (2019) Protydiia transkordonnii zlochynnosti: hlobalnyi kontekst i realii Ukrainy: monohrafiia [Countering cross-border crime: the global context and realities of Ukraine] Odesa: Feniks. 452 p. (in Ukrainian)

8. Filippov S. (2019) The Smuggling of Tobacco Products in Europe: Criminogenic Potential Capacity. Baltic Journal of Law \& Politics. 12: 1. p. 35-61. URL: https://doi.org/10.2478/bjlp-2019-0002

9. Pravyla pol'otiv tsyvil'nykh povitryanykh suden u povitryanomu prostori Ukrayiny. Ministerstvo infrastruktury Ukrayiny, zatverdzheni nakazom Ministerstva infrastruktury Ukrayiny vid 28.10.2011 № 478. [Flight rules for civil aircraft in the airspace of Ukraine. Ministry of Infrastructure of Ukraine, approved by the order of the Ministry of Infrastructure of Ukraine] № 478. From October 28, 2011/ URL: https://zakon.rada.gov.ua/laws/show/z1327-11.

10. Pro zatverdzhennya Aviatsiynykh pravyl Ukrayiny «Pravyla vykorystannya povitryanoho prostoru Ukrayiny : nakaz Derzhaviasluzhby Ukrayiny, Minoborony Ukrayiny vid 11 travnya 2018 № 430/210. [On approval of the Aviation Rules of Ukraine «Rules of use of the Ukrainian airspace: order of the State Aviation Service of Ukraine, Ministry of Defense of Ukraine of May 11, 2018 No. 430 / 210]. URL: https://zakon.rada.gov.ua/ laws/show/z1056-18.

11. Yedynyy zvit pro kryminal'ni pravoporushennya. Forma № 1 (misyachna) : nakaz Heneral'noyi prokuratury Ukrayiny vid 23 zhovt. 2012 r. № 100 [Report on criminal offenses. Form No. 1 (monthly): Order of the Prosecutor General's Office of Ukraine dated 23 October. 2012 № 100]. URL: https://www.gp.gov.ua/en/stst2011.html?dir_id=113897\&libid=.

12. Border security: Additional Actions Could Strengthen DHS Efforts to Address Subterranean, Aerial, and Maritime Smuggling. GAO-17474: Published: May 1, 2017. Publicly Released: May 1, 2017. URL: https://www.gao.gov/assets/690/684408.pdf.

13. Illicit drone flights surge along U.S.-Mexico border as smugglers hunt for soft spots. The Washington Post. June 24, 2018.

14. Filippov S. (2016) Dynamics and Geographical Distinctions of Crime connected with Migrants' Moving to Europe on Different Routes. NATO Science for Peace and Security Series - E: Human and Societal Dynamics. Volume 129. 129 p. P. 21-27. URL: https://doi.org/10.3233/978-1-61499710-8-21. 
15. Filippov S. (2017) Obyvatel'i transgranichnaya prestupnost'. [A Common man and Cross-border Crime]. Pravova derzhava (Constitutional State) No 28. P.107-112.

16. Orlovskaya N (2018) [Criminal threats to the security of cross-border cooperation]. Kryminal'ni zahrozy bezpetsi transkordonnoho spivrobitnytstva. Visnyk Natsional'noyi akademiyi Derzhavnoyi prykordonnoyi sluzhby Ukrayiny. Yurydychni nauky. 2018. № 2. [Bulletin of the National Academy of State Border Guard Service of Ukraine. Legal science]. 2018. No. 2. URL: https://nadpsu.edu.ua/wpcontent/uploads/2018/11/visnik_2_2018_ur.pdf.

17. Gangs used drones and pulleys to smuggle $\$ 80$ million in smartphones from Hong Kong, officials say. The Washington Post. April 2, 2018. URL: https://www.washingtonpost.com/news/morning-mix/wp/ 2018/04/02/gangs-used-drones-and-pulleys-to-smuggle-80-million-insmartphones-officials-say/?noredirect $=$ on\&utm_term $=.9960 \mathrm{~b} 6032 \mathrm{c} 8 \mathrm{c}$

18. Filippov S. O. Zastosuvannya lital'nykh aparativ yak tendentsiya rozvytku transkordonnoyi zlochynnosti u tsyfrovomu sviti [The use of aircraft as a tendency of cross-border crime in the digital world]. Visnyk Natsional'noyi akademiyi Derzhavnoyi prykordonnoyi sluzhby Ukrayiny. Yurydychni nauky. Bulletin of the National Academy of State Border Guard Service of Ukraine. Legal science. 2018. Vol. 4. URL: http://nbuv.gov.ua/UJRN/vnadpcurn_2018_4_7

\section{Information about the author: Stanislav Filippov,}

Ph.D., Associate Professor, LTC Deputy Dean of the Law Enforcement Faculty Bohdan Khmelnytskyi National Academy of the State Border Guard Service of Ukraine 46 Schevchenko str., Khmelnitsky, Ukraine, 29007 ORCID ID: orcid.org/0000-0001-6700-4194 